\title{
Z ZAGADNIEŃ RZYMSKICH IMPORTÓW Z CMENTARZYSKA KULTURY WIELBARSKIEJ W GÓRZYCY NA ZIEMI LUBUSKIEJ
}

SŁowa KLUCzowe: kultura wielbarska; Ziemia Lubuska; Górzyca; importy rzymskie; terra sigillata

Keywords: Culture of Wielbark; Ziemia Lubuska; Górzyca; the roman imports; terra sigillata

\section{INFORMACJE WSTĘPNE}

Birytualne cmentarzysko ludności kultury wielbarskiej odkryte na stanowisku nr 20 w Górzycy, pow. słubicki, woj. lubuskie jest jednym z nowo rozpoznanych stanowisk tej kultury na Środkowym Nadodrzu (Socha, Sójkowska-Socha 2012b: 90-92). Jeszcze do niedawna uważano, że ludność kultury wielbarskiej nie dotarła na Środkowe Nadodrze (Wołagiewicz 1981a: 154-155; Kaczanowski, Kozłowski 1998: 291-293, ryc. 154; Kokowski 2005: 178, mapa 11, 250, mapa 16). Tymczasem prowadzone od kilku lat na tym obszarze ratownicze badania wykopaliskowe, w związku z różnego rodzaju inwestycjami, zmieniają naszą wiedzę na ten temat. Do obiegu naukowego sukcesywnie wprowadzane są nowe stanowiska, wśród których wymienić należy, m.in.: Jordanowo, stan. 12 (Wawrzyniak 2007, 2010); Jordanowo stan. 20 (Rogalski 2009); Myszęcin, stan. 19 (Rogalski 2009); Sulechów, stan. 10, stan. 14 i stan. 29 (Jaszewska, Wawrzyniak 2007: 276-288; Jaszewska 2010: 229-230). Do tematyki osadnictwa ludności kultury wielbarskiej odnoszą się także niektóre nowe artykuły, dotyczące obszarów nad-i zaodrzańskich (m.in. Schuster 2007, 2011; Lewczuk w druku). Zagadnienie to poruszają po części również opracowania badań archiwalnych (Hauptmann 2002; Gałęzowska 2007). Te publikacje 


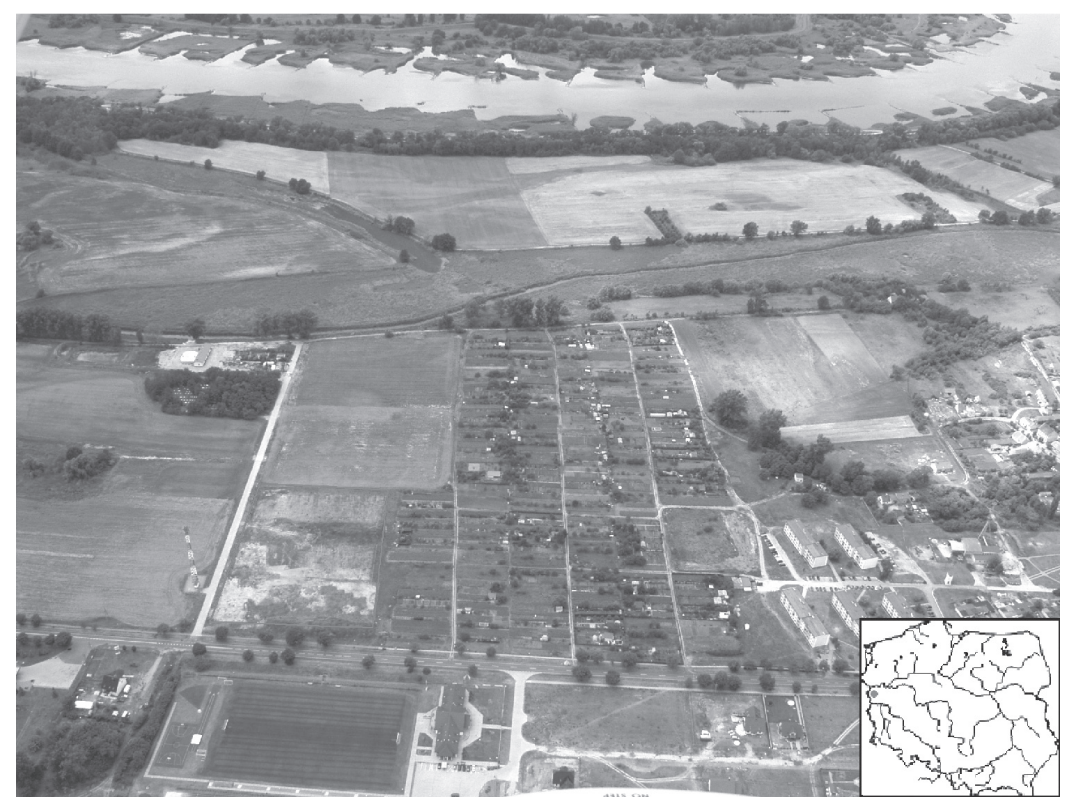

Ryc. 1. Górzyca, pow. Słubice, stan. 20. Lokalizacja stanowiska na fotografii lotniczej z zaznaczonym obszarem badań (biała ramka).

(Źródło: zdjęcie wyk. w ramach projektu ArchaeoLandscapes Europe, fot. W. Rączkowski, oprac. K. Socha)

są cenną bazą źródłową do poznania charakteru osadnictwa ludności kultury wielbarskiej nad środkową Odrą.

Rezultaty prowadzonych w latach 2008-2010 badań ratowniczych w Górzycy publikowane są systematycznie przez prowadzących badania Krzysztofa Sochę i Juliannę Sójkowską-Sochę (2012; 2012a; 2014). Stanowisko znajduje się na obszarze zwanym Lubuskim Przełomem Odry, w pobliżu wspomnianej arterii rzecznej (ryc. 1). Pod względem kulturowym omawiane cmentarzysko związane jest z ludnością tzw. grupy lubuskiej nadłabskiego kręgu kulturowego oraz ludnością kultury wielbarskiej. W świetle dotychczasowych badań funkcjonowało ono od fazy B1 po fazę C1 okresu wpływów rzymskich (Socha, Sójkowska-Socha 2012a: 227-228; 2012a: 112-113). Zamierzeniem autorów niniejszego studium jest omówienie importów rzymskich pozyskanych z odkrytej części cmentarzyska kultury wielbarskiej. Zwrócona zostanie uwaga na funkcję, pochodzenie oraz drogi ich przedostawania się obszar Ziemi Lubuskiej. 


\section{GROBY Z IMPORTAMI Z ,GÓRZYCKIEJ” NEKROPOLI}

$\mathrm{Na}$ „górzyckiej” nekropoli spośród 85 grobów, zbadanych na części cmentarzyska z okresu wpływów rzymskich, około $70 \%$ z nich można z pewnością przypisać do kultury wielbarskiej. Formy odkrytych pochówków były zróżnicowane. W kilku przypadkach przepalone kości ludzkie złożono w popielnicach. Dobrym tego przykładem jest grób - ob. 184 zawierający zdobioną popielnicę o czernionej gładkiej fakturze (misę typu VIA wg Ryszarda Wołagiewicza 1993: 14) oraz złożone nad nią fragmenty pięciu innych naczyń (w tym m.in. misę na nóżce grupy Xb wg Ryszarda Wołągiewicza 1993: 17 oraz naczynie ,jeżowate”, potłuczone, wtórnie przepalone i silnie zdeformowane, co niestety ogranicza możliwości identyfikacyjne). Jednakże dominującą formą grobów są pochówki jamowe, zarówno czyste, jak i z resztkami stosu pogrzebowego. Jamy grobowe maja „,standardowe" kształty i wymiary w granicach od ok. $0,3 \times 0,3 \mathrm{~m}$ do ok. $1,1 \times 1 \mathrm{~m}$, przy głębokości od ok. $0,1 \mathrm{~m}$ do ok. $0,6 \mathrm{~m}$ (Socha, Sójkowska-Socha 2014: 37).

Wyróżniają się groby z konstrukcjami kamiennymi, mianowicie bruk kamienny (ob. 447) o wymiarach 3,22 x 2,72 m nakrywający dwa pochówki jamowe (ob. $449 \mathrm{i}$ ob. 455). Zdiagnozowano również zdekompletowane wieńce kamienne (ob. 330, ob. 461) o średnicach około $4 \mathrm{~m}$ i 5 m (ryc. 2). Wewnątrz obu wieńców znajdowały się pochówki. W północno-wschodniej części wieńca ob. 330 zlokalizowany został pochówek jamowy (ob. 331) wyposażony w m.in. dwa naczynia, grzebień kościany, sprzączkę, przęślik oraz dwie zapinki brązowe typu A.41 i A.128. Z kolei w wieńcu ob. 461 liczyć się należy z dwoma grobami. Pochówek ,główny” (ob. 459) zawierał bogate kobiece wyposażenie, na które składały się m.in. dwa naczynia, liczne przepalone i silnie zdeformowane paciorki szklane (trudne do identyfikacji), wisior opasany z jądrem w postaci kulki szklanej (niestety rozdrobnionej i nieokreślonej) o barwie białej, miedziany rdzeń monety - najprawdopodobniej subaerat, kółko brodawkowate, szpila kościana, grzebienie, fragment srebrnej bransolety żmijowatej oraz okucia szkatułki i klucz (Socha, Sójkowska-Socha 2014: 38).

Kolejną formą obiektów zarejestrowanych na „górzyckim” cmentarzysku są groby szkieletowe. Jamy grobowe w rzucie poziomym miały kształt prostokątny o zaokraglonych narożach. Ich rozmiary zapewne były dostosowane do wzrostu i wieku zmarłego. Jamy orientowano, z małymi odchyleniami, na osi północ - południe. Tylko w dwóch grobach natrafiono na zachowane szczątki ludzkie, ale stan ich zachowania niewiele mówi o ułożeniu ciał zmarłych w grobach (Socha, Sójkowska-Socha 2014: 42). Wyposażenie grobowe stwierdzono 


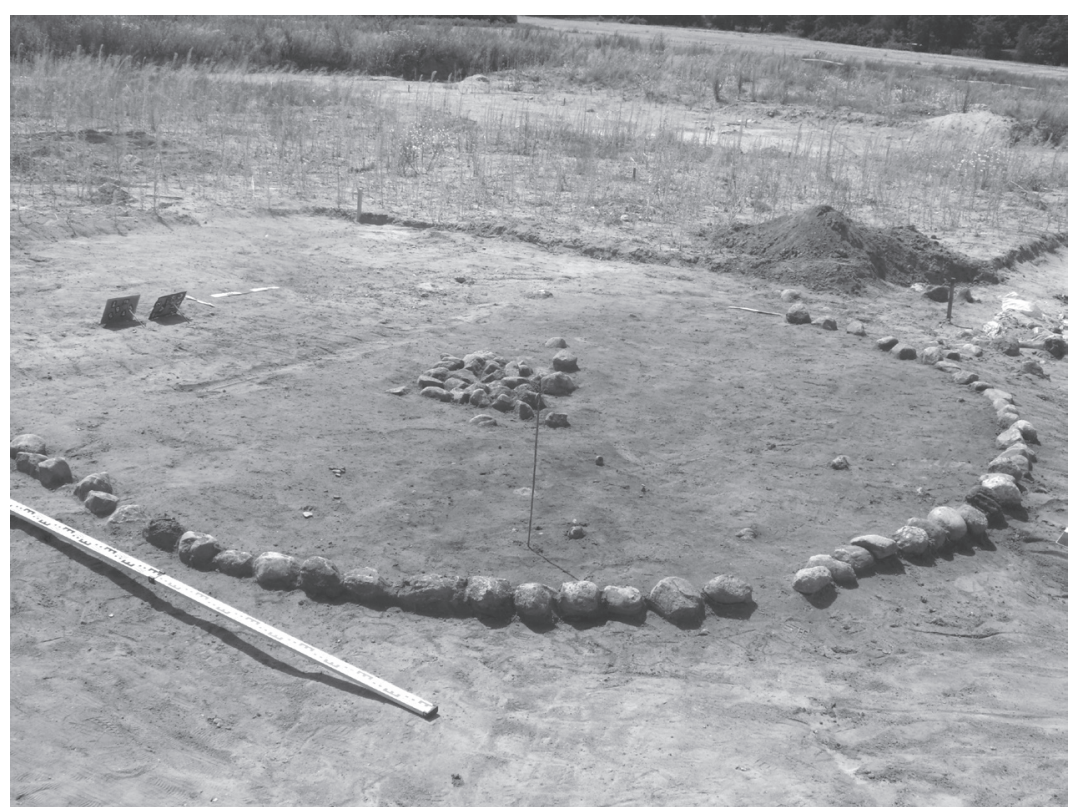

Ryc. 2. Górzyca, pow. Słubice, stan. 20, obiekt 330.

Częściowo zachowany wieniec kamienny na cmentarzysku (Fot. K. Socha)

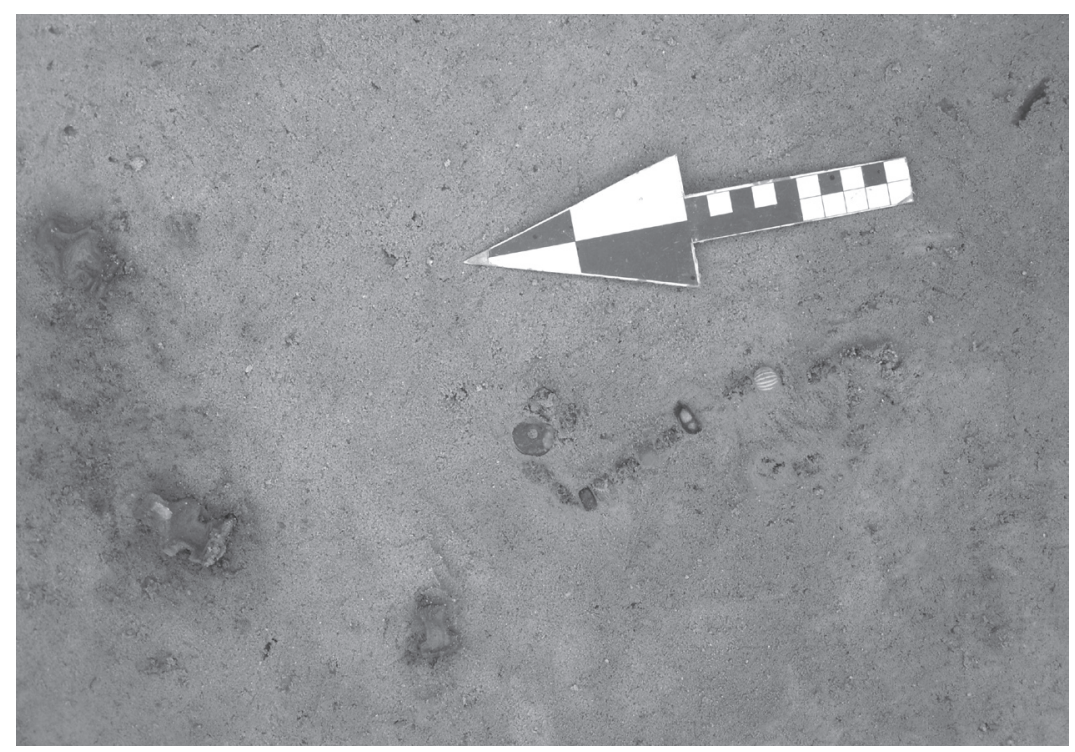

Ryc. 3. Górzyca, pow. Słubice, stan. 20, obiekt 828. Brązowe zapinki A.96 i zapinka A.120 oraz kolia ze szklanych, bursztynowych i kamiennych paciorków na poziomie odkrycia

(Fot. K. Socha) 
w czterech pochówkach, w ob. 95 i ob. 235 były to zaledwie pojedyncze naczynia - kubki. Bogaty zestaw przedmiotów zawierał ob. 198 - grób małego, około 5-6 letniego dziecka. Mianowicie oprócz czterech naczyń (w tym kubków grupy XVwg Ryszarda Wołagiewicza 1993) do grobu złożoną kolię składającą się z 6 paciorków, wykonanych ze szkła, bursztynu i kamienia oraz trzy zapinki brązowe: jedną typu A.193 i dwie zbliżone do typu A.124. W podobny zestaw akcesoriów wyposażono zmarłą z ob. 828, na który składa się kolia złożona z paciorków szklanych (w tym m.in.: paciorków żebrowany grupy XVIII, typ 158b wg Magdaleny Tempelmann-Mączyńskiej, 1985, 19, 39-40, tabl. 3), bursztynowych (w tym, m.in.: paciorków typu $389 \mathrm{wg}$ Magdaleny Tempelmann-Mączyńskiej, 1985: tabl. 15) i kamiennych oraz trzy zapinki brązowe, dwie typu A.96 i jedną typu A.120 (ryc. 3). Na podstawie wyposażenia, głównie zapinek, groby z koliami datować można na datować na fazę B2/C1 okresu wpływów rzymskich (Socha, Sójkowska-Socha 2014: 42).

Zakładać można, że jeden z odkrytych na cmentarzysku obiektów należałoby interpretować jako grób symboliczny (ob. 212), bez śladów kości ludzkich. Pod warstwą kamieni, w spagu obiektu stwierdzono pojedyncze naczynie, paciorek bursztynowy typu 389 wg Magdaleny Tempelmann-Mączyńskiej (1985: tabl. 15), paciorek z niebieskiego szkła (nieokreślony) oraz brązową ornamentowaną blaszkę będąca fragmentem ozdoby (?) (Socha, Sójkowska-Socha 2014: 38).

Do wyróżniającej się kategorii importów prowincjonalnorzymskich zaklasyfikować należy dwie niżej opisane zapinki. Jedna z nich została odkryta w grobie jamowym ciałopalnym (ob. 440). Omawiana fibula należy do dość
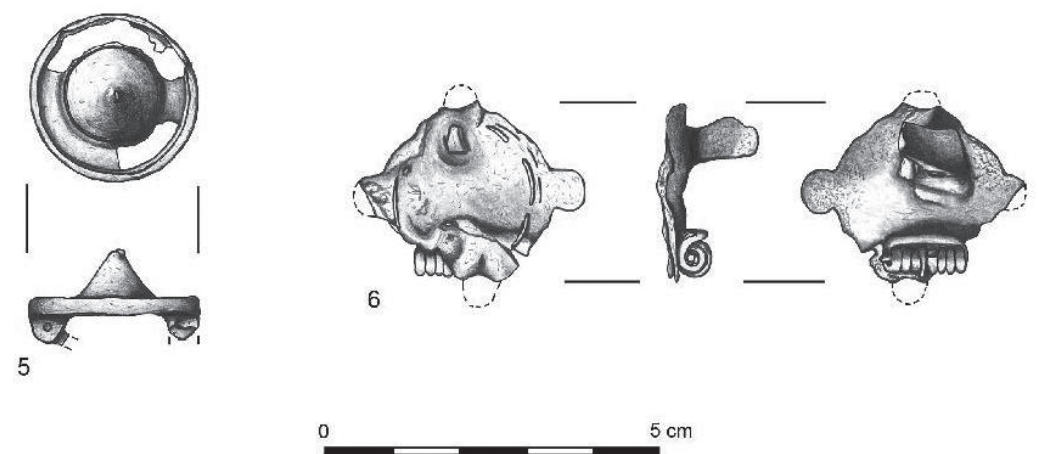

Ryc. 4. Górzyca, pow. Słubice, stan. 20:

A - obiekt 440, zapinka tzw. tutulusowata typu 7.11.1 wg Rihy lub typu 25a wg Feugère'a; B - obiekt 459, zapinka tarczowata typu A wg Thomas

(Rys. J. Sójkowska-Socha) 
popularnej odmiany tzw. tutulusowatej, typu 7.11.1 wg Emilie Rihy (1979: 186-187, tabl. 70:1584) lub typu 25a wg Michela Feugère'a (1985: 351-355, tabl. 148:1867) ${ }^{1}$ (ryc. 4: A). Zapinki tego typu znamy głównie z Galii i Nadrenii, choć spotykane są też w Brytanii, a na wschodzie aż po rzymską Dację i strefę północnych wybrzeży Morza Czarnego. Datowane są na ostatnią tercję I i pierwszą połowę II wieku (Feugère 1985: 351-354). W Barbaricum, między Łabą a Bugiem, tej odmiany dotychczas nie znaleziono. Podobną fibulę, typu Feugère 25b, współwystępującą z zapinkami typu A.76/78, odkryto na cmentarzyska w Kamieńczyku w grobie 63 z fazy B2a (Dąbrowska 1997: 22, 83, tabl. XXX: 63.1). Wśród pozostałego wyposażenia zarejestrowanego w obiekcie 440 wymienić należy fragmenty dwóch naczyń, klucz, sprzączkę, fragmenty brązowej zapinki oraz przepalone i zdeformowane paciorki szklane.

Większą trudność $\mathrm{w}$ identyfikacji, z uwagi na stan zachowania, przysparza zapinka z grobu podkurhanowego (ob. 459 - opis grobu, jak i konstrukcji kurhanu patrz powyżej). Charakteryzowana fibula najogólniej odpowiada typowi A w systematyce „barbarzyńskich” zapinek tarczowatych autorstwa Sigrid Thomas (1967). Zapinka po złożeniu na stosie pogrzebowym bezpowrotnie straciła część swoich cech stylistycznych. Prawdopodobnie pierwotnie posiadała emalię (ryc. 4: B). Jej cechy stylistyczne umożliwiają przybliżone datowanie na III wiek, może jego pierwszą połowę (Socha, Sójkowska-Socha 2014: 41).

W przypadku „górzyckiego" cmentarzyska zapinki stanowiły najczęstszy element wyposażenia odkrywany w grobach. Surowiec z jakiego je wykonano to głównie brąz, rzadziej żelazo, do rzadkości należą zapinki bimetaliczne. Do grobów najczęściej składano dwie fibule, rzadziej jedną. W pojedynczych przypadkach, zarówno w grobach ciałopalnych, jak i szkieletowych, zarejestrowano trzy egzemplarze. Wśród zapinek odkrytych w grobach wyróżnić należy, m.in.: w obiekcie 430 - zapinkę typu A.2; ob. 331 - typu A.41; ob. 97 - typu A.60; ob. 223 - typu A.120; ob. 32 - typu A.124; ob. 331 - typu A.128; ob. 177 - typu A.128; ob. 198 - typu A.193.

\section{BOGATY GRÓB MLODEJ KOBIETY Z TERRA SIGILLATA}

Najbogatsze wyposażenie, w skali przebadanej części cmentarzyska, odkryto w grobie oznaczonym nr 9 (ob.85). Interesujący nas grób - to ciałopalny pochówek jamowy młodej około 20-25 letniej kobiety (Socha, Sójkowska-

\footnotetext{
1 Prowadzący badania w Górzycy, K. Socha i J. Sójkowska-Socha serdecznie dziękują Panu dr Jackowi Andrzejowskiemu za pomoc przy identyfikacji i cenne wskazówki dotyczące importowanych zapinek z obiektów 440 i 459.
} 
-Socha 2012b: 92; Wrzesińska 2012: 122-123). Jama grobowa o wymiarach ok. 70 x $58 \mathrm{~cm}$, wkopana została na głębokość $63 \mathrm{~cm}$. W rzucie poziomym jej zarys przybierał kształt $\mathrm{w}$ przybliżeniu czworokątny o zaokragglonych narożach. Eksploracja przeprowadzona warstwami pozwoliła na odtworzenie kolejnych czynności przy powstawaniu grobu. Materiał zabytkowy i fragmenty przepalonych kości zalegały na wszystkich dziewięciu poziomach eksploracyjnych. Jednak największa ich koncentracja występowała w niższych i spągowych poziomach grobu, od piątego do pierwszego poziomu eksploracyjnego. Tam też zarejestrowano największą ilość potłuczonego naczynia terra sigillata oraz pozostałe naczynia ceramiczne (ryc. 5). Z pewnością do jamy grobowej, najpierw złożono fragmenty sigillata, następnie pozostałe naczynia i inne liczne elementy wyposażenia. Dopiero kolejny etap polegał na zsypaniu do niej przepalonych kości zmarłej kobiety wraz z resztkami stosu (Socha, Sójkowska-Socha 2012b: 93, 106, ryc. 4-8).

Na ceramiczną zastawę ,grobową” zmarłej składały się trzy naczynia zastawy stołowej, tj. ręcznie lepione misa i niewysoki dzbanek oraz wspomniana importowana miska terra sigillata. Dzban jest częściowo przepalony i zniekształcony, zdobiony na szyjce listwą z wyciskanymi dołkami, następnie niżej na brzuścu zespołami skośnych żłobków. Posiada kolankowate ucho z kanalikiem.

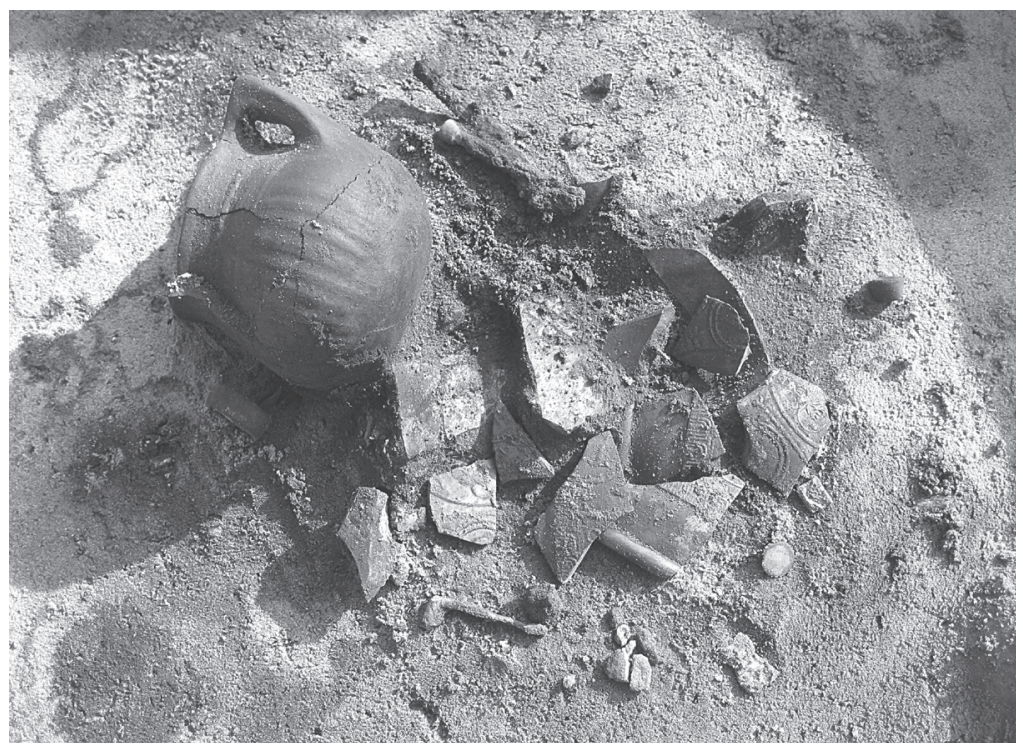

Ryc. 5. Górzyca, pow. Słubice, stan. 20, grób 9 w trakcie eksploracji.

Widoczny dzbanek z kolankowatym uchem z kanalikiem (naczynie grupy IXA wg Wołagiewicza) oraz fragmenty miski terra sigillata

(Fot. K. Socha) 
Typologicznie jest to naczynie grupy IXA wg Ryszarda Wołagiewicza (1993: 16, tabl. 25-26 i 71) (ryc. 5). Podobnie drugie, profilowane misowate naczynie jest silnie przepalone i zniekształcone. Tektonika naczynia wskazuje na misę grupy XaA wg typologii Ryszarda Wołagiewicza (1993: 16-17, tabl. 27 i 73).

Szczególnie cennym przedmiotem był częściowo stopiony, bogato zdobiony filigranem i granulacją złoty wisiorek kulisty. Na jego dolnej części kulistej zachowały się dwie kulki granulacji zdobiące tę część ozdoby. W oparciu o przyjmowaną klasyfikację zaliczyć go należy do typu Ib1 wg Andrzeja Kokowskiego (1991: 118, ryc. 5) i typu Ia wg Jana Schustera (2010: 128-134, ryc. 53). Z monety zachował się tylko miedziany rdzeń, analiza wskazuje, że prawdopodobnie był to subaerat (Socha, Sójkowska-Socha 2012b: 107; Sikora 2012: 118-119).

Wyjątkowym znaleziskiem jest ośródka jurajskiego małża Pholadomya (Socha, Sójkowska-Socha, 2012b: 98, 109, ryc. 12; Jakubowski, Kurzawska 2012: 119-120). Na jej powierzchni zaobserwowano obecność stopionych paciorków szklanych, przedmiotów brązowych oraz przepalonych kości ludzkich. Ośródka należała do wyposażenia i prawdopodobnie stanowiła, wraz z paciorkami szklanymi i przedmiotami brązowymi min. wisiorkiem wiaderkowatym, element niezwykle bogatej kolii. Mogło to być jądro dużego wisiora opasanego. Ozdoby te razem ze zmarła zostały złożone na stosie pogrzebowym, gdzie uległy zniszczeniu - stopieniu i deformacji (Socha, Sójkowska-Socha 2012b: 109).

Wśród pozostałych zabytków odkrytych w prezentowanym grobie wyróżnić należy: fragmenty zapinki brązowej, prawdopodobnie, tzw. kapturkowatej, typu A. II?, wisior szklany (?) opasany taśmą brązową paciorki szklane i zdobione paciorki gliniane, przęśliki, okucia szkatułki, klucz, szpile kościane i metalowe oraz kości zwierzęce (Socha, Sójkowska-Socha 2012b: 97-112).

W grobie tym liczną kategorię importów stanowią zwłaszcza szklane paciorki (ryc. 6). Przynależność typologiczną w przypadku paciorków szklanych udało się określić tylko dla dwóch z nich. Są to paciorki żebrowane grupy XVIII wg Magdaleny Tempelmann-Mączyńskiej (1985: 19, 39-40, tabl. 3). Mimo ich przepalenia i zdeformowania udało się je zidentyfikować typologicznie. Pierwszy z nich to paciorek melonowaty, przezroczysty, o barwie jasnozielonej, typu 158b (ryc. 6: 3). Paciorki tego typu występują przez cały okres wpływów rzymskich, lecz najintensywniej w fazie $\mathrm{B}_{2}$ (Tempelmann-Mączyńska 1985: 94, tabl. 8). Analogie do paciorka typu 158b odnajdziemy m.in. na stanowiskach w Bad Lippspringe, grób 1; Grodzisku Mazowieckim, grób 1; Kowalewku, grób 282 czy też w Opatowie (Tempelmann-Mączyńska 1985: s. 176, por. katalog; Skorupka 2001: 78, 156, tabl. 85:12a). 


\section{0}

100

1. 6.10
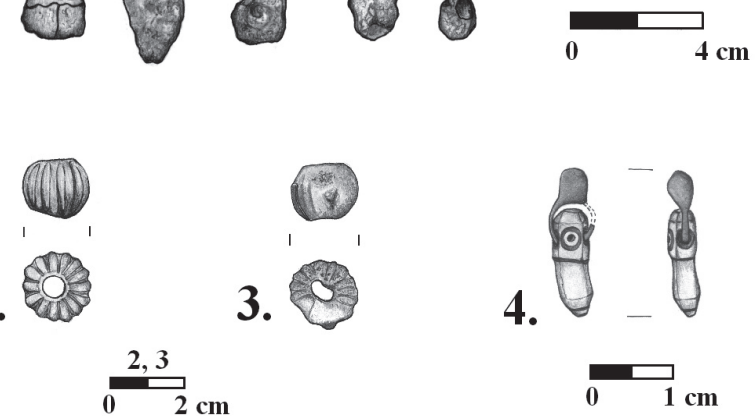

\section{$\stackrel{2,3}{2} \mathrm{~cm}$}

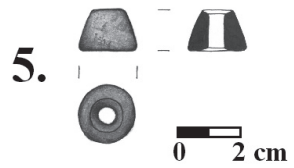

Ryc. 6. Górzyca, pow. Słubice, stan. 20, grób 9: 1-3- paciorki szklane, 4 - paciorek kościany, 5 - paciorek gliniany

(Rys. J. Sójkowska-Socha)

Drugim z rozpoznanych egzemplarzy jest paciorek melonowaty, z tzw. niebieskiego fajansu typu 171 (ryc. 6: 2). Tego rodzaju paciorki rejestrowane są bardzo licznie w inwentarzach kultury przeworskiej i kultury wielbarskiej przez cały okres wpływów rzymskich (Tempelmann-Mączyńska 1985: 41, 94, 177). Największe ich występowanie ma miejsce w fazie $\mathrm{B}_{2}$ i $\mathrm{B}_{2} / \mathrm{C}_{1}$ okresu rzymskiego (Tempelmann-Mączyńska 1985: 94, tabl. 8). Analogiczne paciorki odkryto na stanowiskach m.in. w Horno, Kr. Guben, Kowalewku grób 84; Lubowidzu, groby 52, 109, 176, 192, 268, 290, czy też Pruszczu Gdańskim (Tempelmann-Mączyńska 1985: 177, 237, 292-293, 308-309; Skorupka 2001: 34, 156, tabl. 25).

W omawianym inwentarzu grobowym stwierdzono występowanie również co najmniej 19 paciorków szklanych oraz kilkunastu ich fragmentów, pokruszonych, stopionych i zniekształconych o barwie zielonej, jasnozielonej, 
białej i czerwonej oraz jednej „łezki” stopionego szkła o barwie fioletowej (ryc. 6: 1). Pierwotnie mogły one tworzyć razem kolię. Niestety stan zachowania tych szklanych paciorków nie pozwala na bliższe określenie ich przynależności typologicznej. Jest to charakterystyczne dla ciałopalnego obrządku pogrzebowego praktykowanego przez ludność kultury wielbarskiej.

Wśród zarejestrowanych $\mathrm{w}$ grobie paciorków niezwykle ciekawym wydaje się być egzemplarz kościany o wysokości $1,2 \mathrm{~cm}$, i średnicy $0,4 \mathrm{~cm}$ (ryc. 6: 4). W górnej jego części wykonano otwór, przez który przeciagnięto brązowy drucik zakończony pętelką. Służyła ona zapewne zamocowaniu paciorka do drutu/sznura podtrzymującego całą kolię. Dwie przeciwległe ściany omawianego paciorka kościanego są zdobione ornamentem w postaci dołka otoczonego wyrytym owalem. Jest to egzemplarz nieznajdujący ścisłych odpowiedników w typologii M. Tempelmann-Mączyńskiej (1985: 90-91, tabl. 20).

Ponadto w tym zespole grobowym wystapił również paciorek gliniany typu 497 wg M. Tempelmann-Mączyńskiej (1985: 88-89, tabl. 19) (ryc. 6: 5). W wyniku analizy petrograficznej przeprowadzonej przez dr. M. Szydłowskiego (2012) okazało się, że paciorek ,górzycki” został wykonany z gliny ze znaczną domieszką schudzającą w postaci głównie tłucznia kwarcowego, drobnoziarnistego i drobnych fragmentów miki. Ponadto dla paciorków typu 497 charakterystyczne jest malowanie ich powierzchni (Tempelmann-Mączyńska 1985: 88). Jedyny znany dotąd egzemplarz jest znaleziskiem luźnym z cmentarzyska w Lubowidzu (Tempelmann-Mączyńska 1985: 293).

Omówione powyżej zabytki $\mathrm{z}$ wyposażenia grobowego młodej kobiety dają podstawę do datowania pochówka nr 9 (ob. 85) na fazę B2/C1 (bądź B2/ C1-C1a) okresu wpływów rzymskich (Socha, Sójkowska-Socha 2012b: 113). Miska terra sigillata z omawianego zespołu należy, jak dotychczas, do kategorii wyjątkowych odkryć na Ziemi Lubuskiej.

\section{Miska Laxtucissy, LaXtucissy-Paternusa II}

Miska terra sigillata z Lezoux odkryta w Górzycy była już przedmiotem obszernego opracowania (Tyszler 2012a), z tego względu zasadniczo pominięta zostanie analiza zdobnictwa i stylistyki dekoracji (ryc. 7a, b) ${ }^{2}$. W rozważaniach

\footnotetext{
${ }^{2}$ Warto dodać, że miska odkryta w Górzycy eksponowana była na wystawie „L’archéologie c'est notre hostoire” organizowanej przez Musée départemental de la Céramique w Lezoux. To szczególny przypadek, gdy wytworzone naczynie po przedostaniu się na odległy obszar Barbaricum wraca po ponad 1850 latach dokładnie w miejsce swoich ,narodzin” (http://www. naukawpolsce.pap.pl/aktualnosci/news,395428,spektakularne-zabytki-z-gorzycy-na-wystawiewe-francji.html/http://archeologia.uni.lodz.pl/blog/miska-terra-sigillata-z-grobu-ksiezniczkiw-gorzycy).
} 


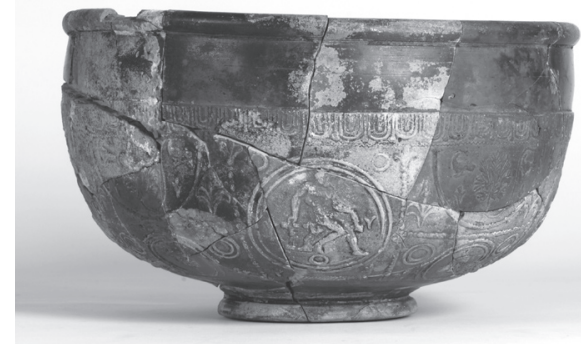

a

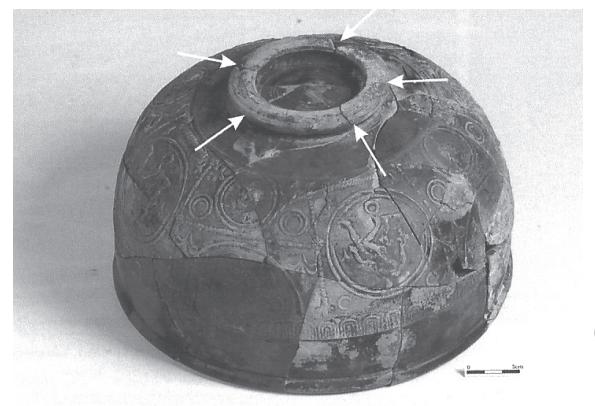

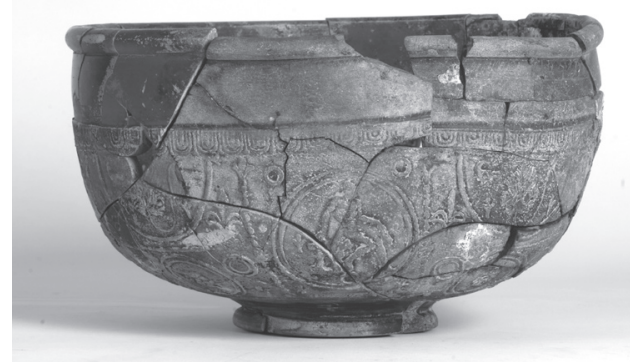

b

Ryc. 7a, b, c. Górzyca, pow. Słubice, stan. 20, grób nr 9 Miska terra sigillata ze środkowej Galii, warsztat Laxtucissa lub Laxtucissa-Paternusa II z Lezoux (Rekonstrukcja K. Socha, fot. W. Pohorecki, L. Tyszler)

C

podkreślić jednak należy istotną cechę naczynia, jako daru grobowego, dającego się skleić w całości (brak 2-3 małych fragmentów; rekonstrukcja Krzysztofa Sochy). Istnieje zatem przesłanka, że reguła pars pro toto nie miała tutaj zastosowania. Z dokonanych oględzin wynika ponadto, że zostało ono intencjonalnie rozbite uderzeniem w zewnętrzną płaszczyznę dna, przed umieszczeniem fragmentów na stosie, bądź w strefie stosu (Tyszler 2012a: 128, ryc. 2) (ryc. 7c). Ich stan zachowania jest różny, od przepalonych, nadpalonych, po nieliczne nieprzepalone. Te ostatnie pozostawały poza zasięgiem działania termicznego.

Zwrócić należy uwagę na to, że w kulturze wielbarskiej znane nam naczynia terra sigillata (tj. różnoczasowe wyroby ze środkowej Galii, Blickweiler, Rheinzabern, Westerndorf i Pfaffenhofen) pochodzą z grobów szkieletowych, gdzie zgodnie z regułą umieszczano je w całości, mianowicie w Weklicach, Sadłowie, Leśnie, Odrach oraz innych stanowiskach. Z kolei w grobach ciałopalnych składano je, podobnie jak w grobach kultury przeworskiej, mniej lub bardziej zdekompletowane, m.in. dające się rekonstruować w 40-20\%, a przykładów dostarczają stanowiska w Czarnówku, Janowie, Pomielinie, Jartyporach $\mathrm{i}$ innych (Tyszler 2012b: $255 \mathrm{i}$ nn, tab. 114-115). 
Wracając do rozpoczętego wątku, miska jest popularną półkulistą formą typu Drag. 37 według typologii Hansa Dragendorff'a (1895) zdobioną reliefową dekoracją i pokrytą pierwotnie jasnoczerwoną polewą. Analiza elementów zdobienia i stylistyki dekoracji wskazuje na warsztat garncarza Laxtucissy (Laxtucissa) lub warsztat garncarzy Laxtucissy i Paternusa styl II (Laxtucissa-Paternus II) zLezoux (por. Tyszler 2012a: s. 128-131, tab. 1). Wobec podobieństw zdobniczo-stylistycznych wyrobów Laxtucisy i Paternusa II nierzadko spotyka się w literaturze tematu atrybucję Lactucissa/Paternus II z Lezoux. Spośród elementów dekoracyjnych naszej miski z Górzycy zwłaszcza kwiat lilii (typ Rogers G 88) skłania do opowiedzenia się za wyrobem Laxtucissy, z kolei głowa Sylena (typ Oswald 1341) uzasadnia przypisywanie naczynia Paternusowi II. Dominującym elementem są cztery duże medaliony z wpisanymi weń czterema wyobrażeniami herosa Herkulesa trzymającego w ręku niewielką symboliczną maczugę i siedzącego na krześle kurulnym (łac. sella curulis), wybitymi tym samym stemplem (ryc. 8a, b).

W państwie rzymskim kult Herkulesa był jedną z najbardziej rozpowszechnionych religii, a sprzyjał temu złożony charakter tego boga-herosa. Źródła o różnym charakterze, w tym liczne epigraficzne dowodzą dużego zainteresowania kultem Herkulesa w Galii (zob. Tyszler 2012a: 132-133; Wojciechowski 2005: 181-182). Zagadnienie wpływu oficjalnej rzymskiej polityki religijnej wobec Herkulesa na repertuar zdobienia środkowogalijskiej zastawy stołowej terra sigillata w okresie cesarstwa, stało się następnie tematem pogłębionych studiów (Tyszler, Jankowiak w druku).

Z dotychczasowych ustaleń wynika, że Laxtucissa posiadał własny warsztat, ale był także jednym z garncarzy pracujących u Paternusa. W nowszej literaturze tematu działalność warsztatu Laxtucissy ujmowana jest w latach 145-170 lub 150-170 (Stanfield, Simpson 1990; Rogers 1999), natomiast warsztaty Paternusa I i II odpowiednio w latach 150-170 i 160-180 (Stanfield, Simpson 1990; Rogers 1999). Okres wytworzenia miski umieszczać możemy na lata od około r. 150 lub r.160 po lata około 170/180.

Współwystępowanie wrażliwego chronologicznie elementu, jakim jest miska terra sigillata z warsztatu Laxtucissy (145/150-170) lub Laxtucissy-Paternusa II (160-170/180) z Lezoux, upoważnia do zaproponowania ram chronologii bezwzględnej zespołu (por. Tyszler 2012a: 133). Określać go można najwcześniej od lat około 150/160 (Laxtucissa) lub od około 160/170 (Laxtucissa-Paternus II) po lata około 180/190, a nawet dłużej (przy uwzględnieniu zakładanego okresu użytkowania/przechowywania naczynia). Ważnym uzupełnieniem zgłoszonej propozycji datowania są rozważania zawarte w kolejnym rozdziale. 

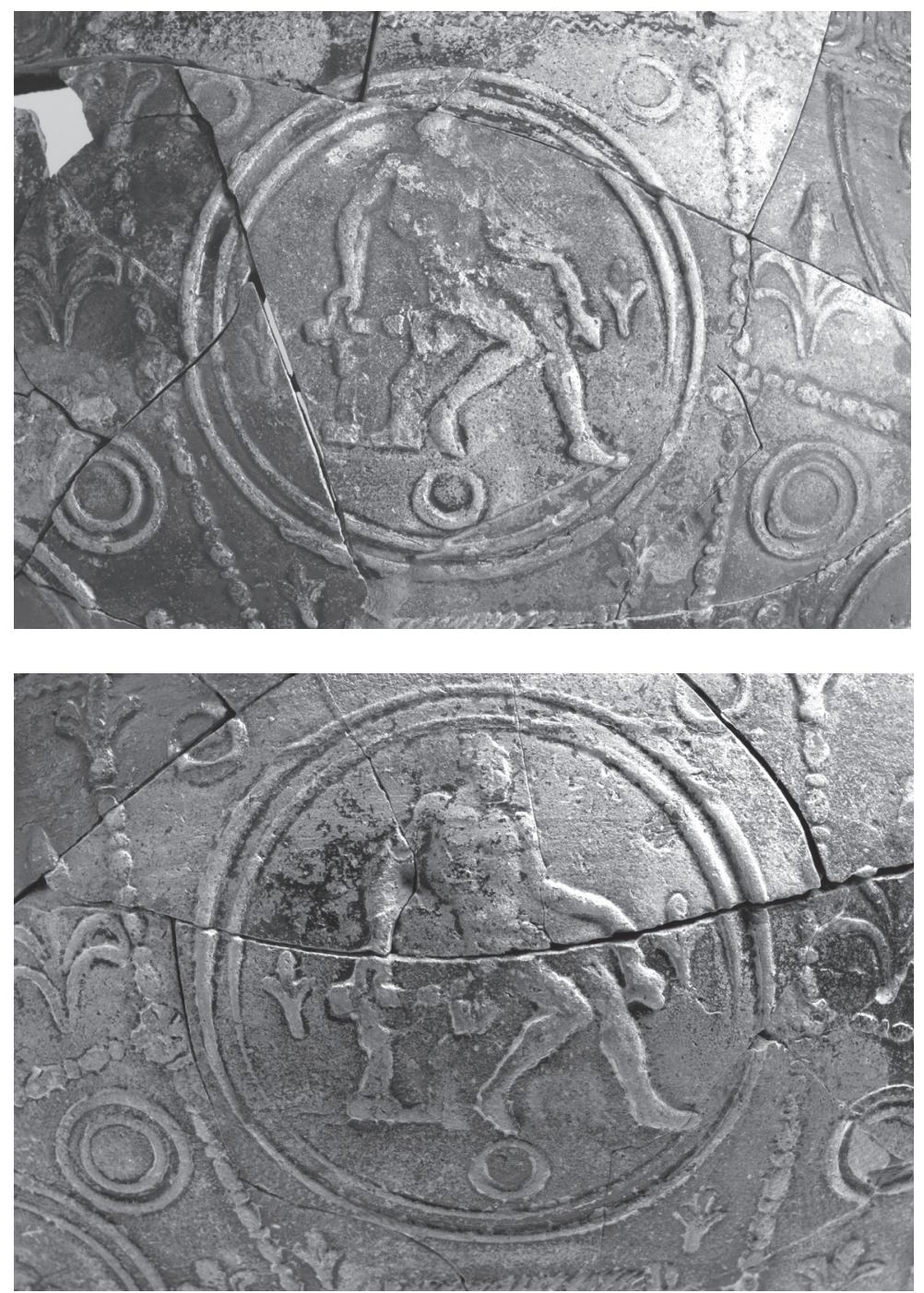

Ryc. 8a, b. Górzyca, pow. Słubice, stan. 20, grób nr 9.

Wyobrażenie herosa Herkulesa trzymającego maczugę w ręku i siedzącego na krześle kurulnym sella curulis (Fot. W. Pohorecki, L. Tyszler) 


\section{Naplyw naczyń LaXtucissy i Paternusa II na obszar Barbaricum}

W kwestii datowania obrotu handlowego tymi naczyniami i ich użytkowania w prowincji Pannonii zwłaszcza pomocne są znaleziska tych garncarzy w warstwach pożarowych stanowisk dotkniętych skutkami wojen markomańskich (z lat 170 i 178, dalej zapis 170/178). W tym kontekście wyroby interesującego nas Laxctucissy odnotowano na stanowiskach górnej i dolnej Pannonii, na stanowiskach w Carnuntum, Aquincum, Pécesvárad (Gabler 1994: 359, 365, tab. 1). Znacznie liczniejsze są materiały Paternusa II zidentyfikowane we wspomnianych warstwach, podobnie na stanowiskach górnej i dolnej Pannonii, mianowicie na stanowiskach w Grosshöflein, Müllendorf, Salla, Arrabona, Brigetio, Aquinqum, Mursa) (Gabler 1994: 360, 365, tab. 1). Znaczący w tych rozważaniach jest kontekst współwystępowania naczyń Laxtucissy i Paterunsa II w depozycie handlowym w jednym ze składów kupieckich w cywilnym mieście w Aquincum w warstwie pożarowej z okresu rzeczonych wojen (Gabler, Kočtur 1977: 75). Mając na względzie dowiedziony okres użytkowania naczyń Laxtucissy i Paternusa II z Lezoux, jak też ustalony koniec dowozu naczyń środkowogalijskich na obszary Recji i Pannonii ogólnie przed końcem (przed 179 r.), bądź wraz z końcem wojen markomańskich (180 r.) (Gabler 1994: tab. 1; Fischer 1981: 68-69, tab. 1; tenże 1994), przedostanie się naszej miski terra sigillata w rejon Górzycy mogło mieć miejsce przed latami 170/178, czy też przed działaniami expeditio Germanica secunda (lata 178-180). Czas użytkowania/przechowywania naczynia na obszarze Barbaricum jest trudny do oszacowania, zakładać można okres około jednej - dwóch dekad (?).

W środkowoeuropejskim Barbaricum wyroby Laxtucissy odnotowane zostały na na obszarze Dolnej Austrii (3 egz.), w Hostínie (okr. Mělník) i Mikulovicach (okr. Pardubice) w Czechach, w Štúrovie (okr. Nové Zámky) w południowo-zachodniej Słowacji, w Kietrzu (pow. Głubczyce) w Polsce oraz w miejscowości Felsözsolca (komitat Miskolc) na Węgrzech (Kuzmovà, Roth 1988: 103, nr 60, ryc. 23:5; Kuzmovà 1994: 245, tab.: Gabler, Vaday 1986: 15, nr 34; Stuppner 1994a: 75, 91/lista, mapa 3; Beljak, Koloník 2007: 135-136, ryc. 1; Halama 2007: 202, ryc. 4:2; Sedláček, Halama, Jílek 2008: 163-165, 171, 173, tab. 1, foto 1-2, ryc. 4, 10; Tyszler 1999, cz. I: 29, tab. 6, 162, tab. 24; taż 1999, cz. II: 39-40, tabl. 24: 1-3, 5; 2012: 16, tab. 18, 360, kat. tab. 2B.C). Najwięcej wyrobów Paternusa lub Paternusa II zidentyfikowanych zostało w Dolnej Austrii (9 egz.), m.in. na stanowisku Seebarn w pobliżu limesu (Stuppner 1994a: 75, 91, 287, nr 118, mapa 2, 4). Znane są ze stanowisk Lužice (okr. Most) 
i Opolany (okr. Numburk) z Czech, z dwóch osad w Nejdek (okr. Břeclav) i Mušov „Zeiselberg” na Morawach (Droberjar 1991: 16-17, nr 42, 44, tab. 4, obr 6:10, 9: 3; Halama 2007: 203, nr 18, 22, obr. 4: 5, 5: 6; Sedláček, Halama, Jílek 2008: 163 i nn., foto 1, obr. 4, 10), oraz może z Konina (pow. Konin) w Polsce (Tyszler 1999, cz. II: 45, kat. 20.1-3, tabl. 27: 1-3 /Albucius lub Paternus II; 2012: 372, kat. tab. 10A.B). Najdalej na wschód docierały na obszary sarmackie na obszar komitatu Békés (Gabler, Vaday 1986: 31, nr 161). Zakładać można, przy obecnym stanie badań, że omawiane wyroby nie docierały na obszar wschodnich Niemiec.

Dyspersja omawianych naczyń Laxtucissy i Paternusa bez wątpienia wskazuje na południowy kierunek ich napływu z dużych naddunajskich ośrodków dystrybucji, m.in. Carnuntum, Brigetio i Aquincum. Koncentracje naczyń atrybuowanych warsztatowi Laxtucissy obserwuje się w Dolnej Austrii (3), w Czechach (2), z kolei nagromadzenie naczyń z warsztatu Paternusa II występuje w Dolnej Austrii (9), na Morawach (2) i w Czechach (2). W oparciu o zgromadzone materiały, najbardziej prawdopodobne jest przedostanie się w okolice Górzycy naczynia Laxtucissy, bądź Laxtucissy-Paternusa II przez obszar Kotliny Czeskiej szlakiem górnej Łaby i następnie górnej Odry. Z drugiej strony nie można eliminować pośrednictwa naddunajskich obszarów dorzecza Morawy. Jak już wyżej wspomniano, rozpoznane dotychczas znaleziska terra sigillata w Saksonii i Brandenburgii wykluczają pośrednictwo tych obszarów w napływie środkowogalijskich wyrobów.

\section{KONKLUZJE}

Częściowo przebadane birytualne cmentarzysko kultury wielbarskiej w Górzycy dostarczyło wcale niemałej liczny importowanych wyrobów prowincjonalnorzymskiego rzemiosła. Przeważają elementy stroju, mianowicie szklane i bursztynowe paciorki składające się na bogate kolie, jak też występujące po kilka. Stanowią typowe akcesorium grobów kobiecych oraz dziewczęcych (?) (zob. grób dziecka 198). Części paciorków nie udało się określić typologicznie ze względu na silną deformację w wyniku przepalenia, czy też wskutek rozkruszenia masy. Są to okazy notowane w fazie B2, a głównie w fazach B2/C1-C1a. Prowincjonalnorzymskiej proweniencji są dwie zapinki, jedna tutulusowata (typu 7.11.1 wg Rihy), druga tarczowata ze zniszczoną emalią (typ A wg Thomas). Do rzadkich znalezisk należą dwie monety, niestety poważnie zniszczone, przypuszczalnie subaeraty wchodzące w skład utensyliów bogatych kobiet. 
Szczególnym importem jest miska terra sigillata $\mathrm{z}$ warsztatów w środkowej Galii, Laxtucissy lub Laxtucissy-Paternusa II z Lezoux, złożona w grobie młodej 22-25 letniej kobiety, pośród innych bogatych utensyliów. Trudno powiedzieć, czy był to wyłącznie dar grobowy, czy może wykwintny element zastawy stołowej użytkowanej przez zmarła. Trzeba przy tym podkreślić, że środkowogalijskie naczynia rzadko docierały na obszary zasiedlone przez nosicieli kultury wielbarskiej. Ze znanych nam dotychczasowych odkryć wymienić należałoby zwłaszcza w całości złożony do grobu szkieletowego egzemplarz miski Cinnamusa z Lezoux odkryty został w grobie 208 datowanym na fazę B2/C1C1a z cmentarzyska w Weklicach (pow. Elblag) (Natuniewicz-Sekuła, Okulicz-Kozaryn 2011: 65 i nn., tabl. 85: 17, 232: 16; Tyszler 2012b: 143/ryc. 34, 145146, 436/ tam literatura). Z kręgiem warsztatów środkowogalijskich(?) łączyć można fragment z cmentarzyska w Kleszewie (pow. Pułtusk) (Tyszler 1999, cz. II: 13; 2012b: 143/ryc. 34), odnotowany w znacznej odległości od interesującego nas obszaru Ziemi Lubuskiej.

Zidentyfikowane na cmentarzysku w Górzycy importy dowodzą kontaktów obszarów Ziemi Lubuskiej z rzymskimi prowincjami. W oparciu o dotychczasowe materiały ich napływ notować możemy od fazy B2 wczesnego okresu rzymskiego, ze szczególnym nasileniem w fazie B2/C1-C1a młodszego okresu rzymskiego.

mgr Krzysztof Socha

ul. Graniczna 1

66-470 Kostrzyn nad Odrą

mgr Julianna Sójkowska-Socha

Stowarzyszenie Naukowe Archeologów Polskich

Oddział Lubuski

ul. Długa 27. PL

66-008 Świdnica koło Zielonej Góry

dr Lubomira Tyszler

Wydział Filozoficzno-Historyczny

Uniwersytet Łódzki

Instytut Archeologii

ul. Uniwersytecka 3

90-137 Łódź 


\section{Bibliografia}

Skróty zastosowane w tekście:

A - Almgren 1923

Drag. - Dragendorff H. 1895

Oswald - Oswald F. 1991

Rogers - Rogers G.B. 1974

Almgren O. (1923), Studien über nordeuropäische Fibelformen der ersten nachchristlichen Jahrhunderte mit Berücksichtigung der provinzialrömischen und südrussischen Formen, Leipzig.

Dąbrowska T. (1997), Kamieńczyk: ein Gräberfeld der Przeworsk-Kultur in Ostmasowien, Monumenta Archaeologica Barbarica, t. II, Kraków.

Dragendorff H. (1895), Terra Sigillata, „Bonner Jahrbücher”, t. 96/97, s. 18-155.

Fischer T. (1981), Zur Chronologie der römischen Fundstellen um Regensburg, „Bayerische Vorgeschichtsblätter”, t. 46, s. 63-104.

Fischer T. (1994), Archäologische Zeugnisse der Markomannenkriege (166-180 n. Ch.) in Raetien und Obergermanien, [w:] Markomannenkriege - Ursachen und Wirkungen, eds. H. Friesinger, J. Tejral, A. Stuppner, Brno, s. 341-354.

Feugère M. (1985), Les fibules en Gaule Méridionale de la conquête à la fin du Ve siècle après J.C., Paris.

Gabler D. (1994), Über die Aussagekraft der Terra Sigillata-Funde bezüglich der Zerstörungen in den Provinzen, [w:] Markomannenkriege-Ursachen und Wirkungen, red. H. Friesinger, J. Tejral, A. Stuppner, Brno, s. 355-369.

Gabler D., Kocztur É. (1977), Terra Sigillata Depotfund aus Gorsium, „Alba Regia”, t. 15 , s. $65-88$.

Gabler D., Vaday A. (1986), Terra sigillata im Barbaricum zwischen Pannonien und Dazien, Budapest.

Gałęzowska A. (2007), Obrzqdek pogrzebowy kultury wielbarskiej w Wielkopolsce, „Acta Universitatis Lodziensis”, Folia Archaeologica, 25, s. 155-234.

Halama J. (2007), Nálezy terry sigillaty v Čechách, [w:] Archeologie barbarů 2006. Archeologické výzkumy v Jižních Čechách, red. E. Droberjar, O. Chvojka, Supplementum, nr 3, České Budějovice, s. 195-240.

Hauptmann Th. (2002), Das germanische Gräberfeld von Prqqno, Kr. Myślibórz (ehem. Rahmhütte, Kr. Soldin), Poznań.

Jakubowski G., Kurzawska A. (2012), Ekspertyza ośródka jurajskiego matża PHOLADOMYA ze stanowiska nr 20 w Górzycy, [w:] Socha K., Sójkowska-Socha J., Grób z birytualnego cmentarzyska ludności kultury wielbarskiej w Górzycy, stan. 20, pow. stubicki, woj. lubuskie, „Archeologia Środkowego Nadodrza", t. 9, aneks, s. 119-120. 
Jaszewska A. (2010), Badania archeologiczne na wybranych inwestycjach drogowych $w$ województwie lubuskim, „Z otchłani wieków”, t. 65, nr 1-4, Archeologia Lubuska, s. 221-232.

Jaszewska A., Wawrzyniak P. (2007), Wstępne wyniki badań archeologicznych przeprowadzonych w 2005 r. na obwodnicy Sulechowa, pow. Zielona Góra, woj. lubuskie, „Archeologia Środkowego Nadodrza”, t. 5, s. 269-297.

Kaczanowski P., Kozłowski J.K. (1998), Najdawniejsze dzieje ziem polskich, [w:] Wielka Historia Polski, t. 1, red. S. Grodziski, J. Wyrozumski, M. Zgórniak, Kraków.

Kokowski A. (1991), Grób wojownika kultury przeworskiej z Orońska, w woj. radomskim, „Acta Universitatis Lodziensis”, Folia Archaeologica 12, s. $105-133$.

Kokowski A. (2005), Starożytna Polska. Od trzeciego stulecia przed narodzeniem Chrystusa do schyłku starożytności, Warszawa.

Kuzmovà K. (1994), Die Markomannenkriege und der Terra Sigillata-Import im Vorfeld des nordpannonischen Limes, [w:] Markomannenkriege - Ursachen und Wirkungen, eds. H. Friesinger, J. Tejral, A. Stuppner, Brno, s. 245-251.

Kuzmovà K., Roth P. (1988), Terra sigillata v barbaricu. Nálezy z germánskych sídlisk a pohrebisk na územi Slovenska, Nitra.

Lewczuk J. (w druku), Kultura wielbarska na Środkowym Nadodrzu, [w:] Materiały z Sympozjum „Kontakty ponadregionalne kultury wielbarskiej”, 20-21 października 2011, Gdańsk.

Natuniewicz-Sekuła M., Okulicz-Kozaryn J. (2011), Weklice. A Cemetery of the Wielbark Culture on the Eastern Margin of Vistula Delta (Excavations 1984-2004), Monumenta Archaeologica Barbarica, t. 17, Warszawa.

Oswald F. (1991), Index des types-figurés sur céramique sigilée. Descriptions de motifs de J. Déchelette, Fasc. 1-2, Revue Archéoloqique, SITES, hors-série, nr 19, Lezoux.

Riha E. (1979), Die römischen Fibeln aus Augst und Kaiseraugst, Augst.

Rogalski B. (2009), Groby z młodszego okresu przedrzymskiego i okresu wpływów rzymskich na stanowisku 20 w Jordanowie, pow. Świebodzin, ,Wielkopolskie Sprawozdania Archeologiczne", t. 10, s. 87-101.

Rogers G. B. (1974), Poteries sigillées de la Gaule Centrale, I-Les motifs non figures, XXVIII ${ }^{\mathrm{e}}$ supplément à Gallia, Paris.

Rogers G. B. (1999), Poteries sigillées de la Gaule Centrale, II - Les potiers, t. I-II, Cahier du Centre Archéologique de Lezoux, SITES, hors-série, nr 40, Lezoux.

Schuster J. (2007), Wptywy wielbarskie na wschód od Odry, [w:] Nowe materiaty i interpretacje. Stan dyskusji na temat kultury wielbarskiej, red. M. Fudziński, H. Paner, Gdańsk, s. 433-456. 
Schuster J. (2010), Lübsow. Älterkaiserzeitliche Fürstengräber im nördlichen Mitteleuropa, Bonn.

Schuster J. (2011), Wielbark - Przeworsk - Luboszyce. Z badań nad stosunkami kulturowymi na przełomie II/III wieku między środkowa Łabq a Odra, [w:] Nadodrze w starożytności, Konferencja Grabice, 23-30 czerwca 2004 roku, red. G. Domański, Zielona Góra, s. 141-161.

Sedláček R., Halama J., Jílek J. (2008), Nové germánské sídliště s nálezem terry sigillaty v Mikulovicich, okr. Pardubice, [w:] Barbarská sídliště, eds. E. Droberjar, B. Komoróczy, D. Vachútová, Brno, s. 161-176.

Sikora M. (2012), Analiza numizmatyczna zabytku odkrytego $w$ grobie 9 na stan. 20 w Górzycy, pow. stubicki, [w:] Socha K., Sójkowska-Socha J., Grób z birytualnego cmentarzyska ludności kultury wielbarskiej w Górzycy, stan. 20, pow. stubicki, woj. lubuskie, „Archeologia Środkowego Nadodrza”, t. 9, s. 118-119.

Socha K., Sójkowska-Socha J. (2012a), Uzbrojenie społeczności grupy lubuskiej z cmentarzyska w Górzycy, pow. stubicki, [w:] Z najdawniejszych dziejów. Grzegorzowi Domańskiemu na pięćdziesięciolecie pracy naukowej, red. A. Jaszewska, Zielona Góra, s. 223-237.

Socha K., Sójkowska-Socha J. (2012b), Grób z birytualnego cmentarzyska ludności kultury wielbarskiej w Górzycy, stan. 20, pow. słubicki, woj. lubuskie, „Archeologia Środkowego Nadodrza”, t. 9, s. 89-126.

Socha K., Sójkowska-Socha J. (2014), Od birytualnego cmentarzyska ludności kultury mogiłowej po osadę średniowiecznq. Wstępne wyniki badań wykopaliskowych wielokulturowego stanowiska nr 20 w Górzycy, pow. stubicki, „Archeologia Środkowego Nadodrza", t. 11, s. 7-52.

Stanfield J.A, Simpson G. (1958), Central Gaulish Potters, London (Oxford).

Stanfield J.A, Simpson G. (1990), Les potiers de la Gaule Centrale, Revue Archéologique SITES (b.m.w.).

Stuppner A. (1994a), Terra Sigillata im Nördlichen Niederösterreich, „Münstersche Beiträge zu antiken Handelsgeschichte", nr 13, s. 70-94.

Stuppner A. (1994b), Zu den Auswirkungen der Markomannenkriege im niederösterreichischen Limesvorland, [w:] Markomannenkriege - Ursachen und Wirkungen, red. H. Friesinger, J. Tejral, A. Stuppner, Brno, s. 285-298.

Szydłowski M. (2012), Ekspertyza makroskopowa zabytków glinianych i kamiennych z grobu 9 ze stan. 20 w Górzycy, pow. stubicki (aneks), [w:] Socha K., Sójkowska-Socha J., Grób z birytualnego cmentarzyska ludności kultury wielbarskiej w Górzycy, stan. 20, pow. stubicki, woj. lubuskie, „Archeologia Środkowego Nadodrza", t. 9, s. 121. 
Tempelmann-Mączyńska M. (1985), Die Perlen der römischen Kaiserzeit und der frühen Phase der Völkerwanderungszeit im mitteleuropäischen Barbaricum, Mainz am Rhein

Thomas S. (1967), Die germanischen Scheibenfibeln der römischen Kaiserzeit im freien Germanien, Berlin.

Tyszler L. (1999), Terra sigillata na ziemiach Polski, cz. I. Tekst, cz. II, Katalog, Tablice, Łódź.

Tyszler L. (2012a), Środkowogalijska miska terra sigillata z wyobrażeniem Herkulesa z grobu ciałopalnego w Górzycy, stan. 20, pow. stubicki, „Archeologia Środkowego Nadodrza", t. 9, s. 127-137.

Tyszler L. (2012b), Ceramika rzymska na północ od Karpat i Sudetów, Spatium Archaeologicum, t. 4, Łódź.

Tyszler L., Jankowiak A. (w druku), The symbolism of Hercules against the religious, political propaganda of the Roman Empire on the example of terra sigillata bowl discovered in Górzyca, Stubice County, [w:] Ceramika i szkło w kulturze antyku i średniowiecza europejskiego, Wrocław.

Wawrzyniak P. (2007), Wstępne wyniki badań cmentarzyska birytualnego ludności kultury wielbarskiej w Jordanowie, gm. Świebodzin, woj. lubuskie, [w:] Nowe materiaty i interpretacje. Stan dyskusji na temat kultury wielbarskiej, red. M. Fudziński, H. Paner, Gdańsk, s. 527-553.

Wawrzyniak P. (2010), Jordanowo - gocka nekropolia sprzed 2000 lat, „Z otchłani wieków", t. 65, nr 1-4, Archeologia Lubuska, s. 75-80.

Wołąiewicz R. (1981), Systematyka kulturowa, [w:] Prahistoria ziem polskich, Późny okres lateński i okres rzymski, t. V, red. J. Wielowiejski, Wrocław, s. $138-156$.

Wołąiewicz R. (1993), Ceramika kultury wielbarskiej między Battykiem a Morzem Czarnym, Szczecin.

Wojciechowski P. (2005), Czciciele Herkulesa w Rzymie, Toruń.

Wrzesińska A. (2012), Ekspertyza antropologiczna ciałopalnych szczatków ludzkich z grobu 9 w Górzycy, pow. stubicki (aneks), [w:] Socha K., Sójkowska-Socha J., Grób z birytualnego cmentarzyska ludności kultury wielbarskiej w Górzycy, stan. 20, pow. stubicki, woj. lubuskie, ,Archeologia Środkowego Nadodrza", t. 9, s. 122-123. 


\section{SUMmary}

\section{ON THE ISSUE OF THE ROMAN IMPORTS FROM A CEMETERY OF THE WIELBARK CULTURE IN GÓRZYCA IN LUBUSZ LAND}

The archaeological site no. 20 in Górzyca is one of the newly identified biritual cemeteries of the Wielbark Culture in the Middle Odra Region. There were conducted intensive rescue researches in the years 2008-2010. Several characteristic burial structures, namely stone pavements and stone wreaths were discovered in the exposed part of the cemetery. In the inventories of many burials the Roman imported artifacts were found. The most numerous among them are glass and amber beads, usually the components of necklaces which were the equipment of rich women (ob. 828, ob. 85) and a child (ob. 198). Two fibulae made of bronze stand out from the rest artifacts, one of Riha 7.11.1 type or Feugere 25a type (ob. 440) and the second, damaged with an enamel (?) of Thomas A type (ob. 459). To the findings from the rich graves belong two damaged coins, presumably subaerati.

A 22-25 year old young woman's burial had particularly rich equipment (grave no. 9/ob/85), containing imported objects, a rich necklace composed of i. a. numerous glass and amber beads, and a relief bowl of Drag. 37 type from Lezoux. The imported vessel, originated from the workshop of Laxtucissa (145-170 or 150-170) or LaxtucissaPaternus II (160-170/180), allows us to propose a determination of the lower date of burial for about $150 / 160$ or $160 / 170$ (depending on the established attribution of vessel). The manufactures of listed potters belong to the horizon of the Marcomanni wars and are found in many sites in Pannonia in the layers of destruction from the aforementioned wars.

The cartographical study of the distribution of Laxtucissa's and Paternus II's (or Paternus) vessels discovered in areas to the north of the middle Danube indicates their presence in Lower Austria, Czech, Moravia, Slovakia, between Pannonia and Dacia, and in Poland.

The Roman imports, identified in the cemetery in Górzyca, proves contacts between the South and Lubusz Land especially in the phases B2/C1-C1a. 